\title{
Expanding Female Capacity for Poverty Reduction: Strategies for Sustainable Development in Africa
}

\author{
Maria Chinecherem Uzonwanne \\ Nnamdi Azikiwe University Awka, Anambra State, Nigeria
}

\begin{abstract}
Africa has been struggling for many decades to reduce poverty. But there is every indication that the rate of poverty has not slowed down. The average poverty rate for Sub-Saharan Africa alone stands at about $41 \%$. Hence, this study investigated the extent to which female capacity in the African continent has been expanded for poverty reduction for the sample period of 1990-2018 based on the Sen's Capability theory of poverty. In other to achieve the objectives of the study, poverty headcount ratio at $\$ 1.90$ a day for Africa, a proxy measure for poverty on the continent is specified as a function of female labor force participation rate as percentage of total female labor force (as a proxy for income generated by females in Africa), school enrollment (secondary) for females in Africa and life expectancy at birth for females in Africa. The method of autoregressive and distributed lag model analysis was used to analyze the time series data. Findings revealed that school enrollment for females in Africa (SCH) showed negative and significant impact on poverty headcount ratio in Africa in the long run. As recommendation however, effective women education policy interventions should be implemented by the leaders in education sector in Africa to mitigate against the increasing rate of poverty suffered in Africa.
\end{abstract}

Keywords: Poverty, Women, Education, Health and Employment

JEL Code: O15. D6, J24, K12

DOI: $10.7176 / \mathrm{JESD} / 11-20-02$

Publication date:October $31^{\text {st }} 2020$

\section{Introduction}

The World Bank has it that the objectives of development and more so, sustainable development include sustained increases in per capital output and incomes, expansion of productive employment and a higher equity in allocation of the proceeds from growth. This implies reducing poverty and human misery by increasing the productivity of the poor and providing them greater access to health, education, goods and services (Sen, 2000; World Bank, 2017).

The struggle to reducing poverty on the African continent has been intensified both by national and international bodies but there are every indication that the rate of poverty has not slowed down rather it is increasing daily In 2018, the world bank explained international poverty line as those who do not live above $\$ 1.90$ US in a day and thus live on the very edge of survival. The average poverty rate for sub-Saharan Africa alone stands at about $41 \%$, making Africa the continent with the highest level of poverty as pictorially shown below:

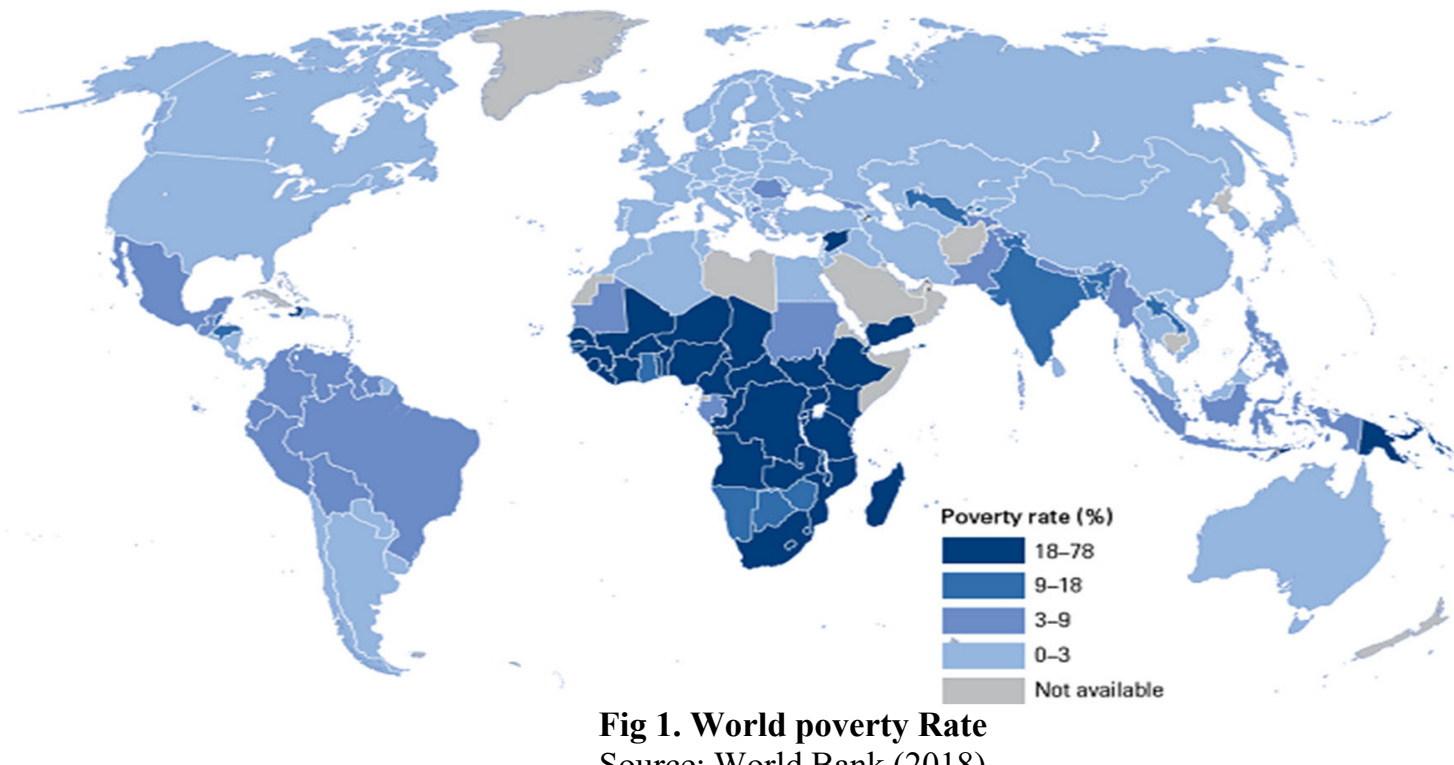

Source: World Bank (2018)

Figure 1 above shows that most of the 43 countries with poverty rates above 18 percent are in Sub-Saharan Africa region. It also describes that of the world's 28 poorest countries (that is, those with the highest rates of 
poverty), 27 are in Sub-Saharan Africa, all with poverty rates above 30 percent. $75 \%$ of Sub-Saharan African countries had poverty rates above 18 percent in 2015, and in 11 countries, all in Sub-Saharan Africa, more than half the population live in extreme poverty especially women (World Bank, 2018).

According to Africare (2020), many African families rely on women to provide basic necessities for survival. Education empowers African women to provide their households with superior nutrition, stronger food security and increased access to health care. However, these contributions of women towards their families and the community in general are less found in Africa since Sub-Saharan women constitute only 15\% of the region's landholders, and they face unequal difficulties starting from sexual abuse to illiteracy and disease. Before now, Asia and its Pacific Region used to have the largest concentration of poverty according to the International Fund for Agricultural Development (IFAD) report in 2002 and this stands out for its startling inequality of gender relations. But in recent time, IFAD (2002) has it that Asia and its Pacific Regions has managed to reduce the rate of poverty in their continent through developing a strong policy that looks towards the enhancement of women in Asia. This policy displayed the evidence that shows that enhancement of women's agency role is the key strategic policy to change gender relations and to rebuild societies with greater social and economic capacity towards reducing poverty and increasing the general lots of the populace.

In Africa today, a lot of young women remain outside the scope of what should be their full economic and self-empowerment potential and this has ransacked Africa of an important section of her economic measures needed to offshoot sustainable development. [African Union Development Agency (AUDA), 2019]. An ILO report in 2016 has it that in the face of endemic poverty on the continent, being young and female in Africa serves as a double strike for those seeking to find productive employment (ILO, 2016). The report further asserts that more than $75 \%$ of inactive out of school young persons are female. As a result, the report noted that African women go on to face higher unemployment rate, persistent wage gaps, and longer school-to-work transition, etc. Following all these limitations on women capability building and the need to curtail poverty on the continent, the reoccurring question that however comes to mind entails whether improving the health, income and school enrolment for African women can help expand female capabilities for poverty reduction and sustainable development on the continent of Africa.

Following the yearnings for sustainable development in the global sphere, this study however, is based on investigating the extent to which female capacity on the African continent has been expanded for poverty reduction strategies and development. As a sharp deviation of other studies (such as Weinstein, 2019; Ozoh, Metu, Chukwuka and Madueke, 2020), this study focuses on the female gender in Africa without being country specific. Also, this study adopted United Nation (UN) capacity strategies as embedded in the Human Development Index (HDI) in order to answer the key question of whether health, income and school enrolment for African women can help expand female capabilities for poverty reduction and sustainable development on the continent of Africa.

\section{Review of Related Literature \\ 2.1 Conceptual framework}

Poverty has been described by various authors from different perspective and view of the term. For instance; Poverty is seen as a state of deprivation in terms of economic and social indicators such as income, employment, education, health care, access to food, social status, self-esteem and self-actualization (Okoh, 2007). Similarly, Obadan (2006) refer to the poor as those who are unable to obtain an adequate income, find a suitable job, own property or maintain a healthy living standard. From the views of Aku, Ibrahim and Bulus (2007) also poverty can be explained from five dimensions of deprivation. They include (i) persons who do not have physical and basic requirements such as shelter, clothing, food, education and health (ii) persons who do not have economic control such as property, capital, income, factors of production and assets (iii) persons who do not freedom to social association (social deprivation) (iv) persons who do not have opportunity to cultural values, beliefs, information (cultural denial), knowledge and (v) persons who do not have political voice contribute in decision making that influences their lives. World Bank (2018) defines poverty as hunger, being sick, having no shelter and opportunity to attain education, being jobless, not having access to health care, having fear for the future and lack of income for daily leaving. According to them, powerlessness and lack of representation and freedom are also associated with poverty. Human development index on their own side associated poverty with life expectancy at birth, educational level and improvement in standard of living as determined by capita income and United Development Programme (UNDP) adopted the same Human Development Index (HDI) for measuring the level of poverty in a country. HDI combines in determining poverty level. As measures of poverty, World Development Report (2018) uses income level of less than US \$ 370 a year or a dollar a day as benchmark for determining poverty. This implies that poverty is linked with the quality of life of people, their literacy level, as well as their income status. For the furtherance of this study, the working definition for poverty is based on the submission of the World Bank (2018) positing that poverty is hunger, lack of shelter, being sick and not being able to go to school, not having a job, fear for the future, losing a child to illness brought about by poor hygiene and lack of finance. Although poverty is defined in different ways, majority of the authors seem to agree that poverty has characteristics which entails health 
deprivation, low income and poor access to education.

\subsection{Theoretical Literature}

The theoretical foundation behind this work is based on the endogenous growth model.

Sen's Capability Theory of Poverty

This study is anchored on the Sen's Capability Theory of Poverty propounded in 1981. Amartya Sen in his book, 'Development as Freedom' has emphasized on Poverty as Capability Deprivation in underlining the theory of poverty. The theory asserts that Poverty must be seen as the deprivation of basic capabilities rather than merely taking into account the income aspect which forms a measure as to whether the person is poor or not. According to Sen's capabilities approach, development should focus on maximizing what an individual can choose to achieve in life such as the ability to choose the many different cultural values and practices to adopt etc. This as a matter of fact will affect the individual well-being which is understood to mean the real enjoyment of the individual's choices stemming from the varieties of option accessible to them. Thus, unlike utilitarianism and libertarianism, the competence and well-being approach look at the variety of options accessible for the individual to choose from and the liberty to exercise that choice (Suraidi, 2014). Sen (2000) proposed that poverty will not focus on the economic measures but measures of human rights and access to basic necessities. In the light of these, Amartya Sen proposed that there are five general freedoms which underpins capabilities, which when people are deprived off, will give rise to poverty:

1. Political freedom including civil rights;

2. Economic facilities which includes access to credit; etc

3. Social opportunities which include arrangements for access to health care, education and other social services;

4. Transparency in relations between people and between people and governments; and

5. Protective security which includes social and economic safety nets such as unemployment benefits and famine and emergency relief.

This study finds this theory useful as it tries to explain that poverty is no longer confined to the issue of income status of African women, rather it looks at the idea of whether an individual is able to enjoy the full range of choices such as education, healthcare, nutrition, good standard of living etc. and then have the actual ability to realize the choice that the women have made.

\subsection{Empirical Literature}

The empirical literature is done following the three main variables this study looks at: education, health and employment.

In 2020, Ozoh, Metu Chukwuka and Madueke Carried out a descriptive research survey. Their work aimed at examining the movement alleviation program and dimension of poverty among women who are into MSMEs (micro small and medium scale enterprises) in Anambra State. The findings of their study showed that most women participating in micro business are not aware of poverty reduction programs and do not have access to such programs. Their recommendation indicates that for the government to eradicate poverty, they should target their policies towards good infrastructure, good health care system, etc.

Weistein (2019), conducted a study to investigate the influence of Women's Empowerment as a Policy for Poverty Reduction in Haiti using the feminist theories of De Beauvoir and Friedan in alignment with the empowerment theory of AlMaseb and Julia as the basis. The research inquiries focused on the participants perception on the idea of empowerment and strategies applied by DINGOs. Facts were collected from a purposive sample of seventeen (17) participants applying e-mail interviews. Their results signposted that (a) all participants shared similar views that the empowerment of Haitian women is a winning strategy for poverty reduction; (b) Participants believe that diaspora NGOs programs are effective, however, there is lack of government participation, corporations with larger NGOs, and necessary resources to remain sustainable. Hence, the study strongly advocates government intervention in the continuous increase of women empowerment in Haiti.

Women in MSSEs (micro small-scale enterprises) in Dekina were assessed for their impact on poverty reduction through the use of logistic regression approach by Audu and Okpe (2018). Their study found that they are positively related. The study therefore recommends that women in MSSEs should form co-operative societies so that they can pool resources together to finance their businesses and also that the local government of Dekina in Kogi state of Nigeria can create an environment that is enabling by providing them with necessary facilities and farming equipment so that they will have more opportunity to venture into MSSEs.

Using a survey design, Maziku, Majenga and Mashenene (2014) explored the effects the socio-cultural factors on women SMEs performance in Tanzania. The research discovered that women immobility and poor support (socio-cultural factors) from the members of their society and ethnicity affects the performance of women SMEs negatively. Hence, the study concludes that SCFs have negative effect on the performance of women SMEs. It was recommended that the government should formulate policies that encourage women participation in 
entrepreneurial activities for their sustainability.

SMEs, alleviation of poverty and creation of job was studied in connection with income generation by Jonathan, Victor and Tuluma (2013). They used burnt brick layers from Benue State of Nigeria for their survey. Their outcome shows that the above-mentioned variables has a strong correlation with income generation in Benue state. The research endorses that the identified challenges which hinder income generation such as poor infrastructure, low prices of bricks, low demand for bricks, and low operating capital confronted by these SMEs should be checked by the various tiers of Nigerian government and finical system as a practical means of job creation, poverty alleviation and income generation for the country.

Tundui (2012) examines gender and small businesses in Tanzania. Using survey design and a sample size of 310 owner-managers in Tanzania, the study found that women are unlikely to aim high as compared to men due to different socialization experiences. The study finally recommends continuous education of women for development of Tanzania.

Ajala and Fakoya (2003) using frequency tables, percentages and chi-square, examined the role of women on small scale business activities on poverty reduction in Oyo state. Structured questionnaires to gather data from one hundred and eighty SMEs women entrepreneurs in Oyo state. The outcome of their research shows a positive relationship between the SMEs and poverty reduction in Oyo state of Nigeria. Therefore, they endorse that the difficulties of poor infrastructure, low prices of bricks, low demand for bricks, and low operating capital faced by these small-scale enterprises should be addressed by the various tiers of government and the financial system as a feasible means of job creation, poverty alleviation and income generation in Oyo State of Nigeria.

In 2003, ILO (international labor organization) carried out a research in Zambia to know how women entrepreneurs creates employment in Zambia. It was a research that involved one hundred and eighteen (118) women entrepreneurs that owns one hundred and forty-four firms (144) in Zambia. Their research shows that Zambia entrepreneur women provided employment for one thousand thirteen persons (1013). Among these, nine hundred and seventy-three (973) of the employees were full-time employees. This according to represents an average of 8.2 full- time employees per firm. Hence, they recommend women empowerment.

\section{Data and Methods}

All data used for this study are collected from World Bank Data Base. It is a times series data which spans the time period 1990-2018.

In order to fully investigate strategies for sustainable development in Africa through expanding female capability and reducing poverty, an open macroeconomic model is specified following (Nwora, 2019), however with some little modifications. The study argued that a framework linking the various means of expanding female capability was needed to be able to fully analyze the strategies for sustainable development in Africa. As such, the human development index model augmented with the postulations of Amartya Sen (1981) argument on poverty which impedes people staying alive and enjoying a long and healthy life, reproducing and transmitting their culture to future generations, interacting socially, having access to knowledge and enjoying freedom of expression and thought is employed. The model explores the linear relationship between female labor force participation rate as percentage of total female labor force (as a proxy for income generated by females in Africa), school enrollment (secondary) for females in Africa, life expectancy at birth for females in Africa, school enrollment (secondary) for females in Africa and poverty headcount ratio at \$1.90 a day (2011 PPP) for Africa and the model is stated functionally thus:

$P O V=F\{$ LIFE, LAB, SCH $\}$

Where:

POV $=$ Poverty headcount ratio at $\$ 1.90$ a day (2011 PPP) for Africa;

LIFE $=$ Life expectancy at birth for females in Africa (A proxy for the health capability of female in Africa)

$\mathrm{LAB}=$ Female Labor force participation rate as percentage of total female Labor force (as a proxy for income generated by females in Africa)

$\mathrm{SCH}=$ School enrollment (secondary) for females in Africa

For the purpose of empirical computation equation 1 converges to an econometric form as given below: $P O V=\beta_{0}+\beta_{1} L I F E+\beta_{2} L A B+\beta_{3} S C H+\mu_{t}$

This study adopts the ARDL bound testing approach developed by Pesarem and Shin $(1995,1999)$ to estimate the long run equilibrium and to establish the direction of causation between variables employed in the study. This methodology became necessary because the data collected are in time series and are not country specific to warrant a panel data survey. Also, variables were identified to be integrated of $\mathrm{I}(0)$ and $\mathrm{I}(1)$ and the model is a single equation. The advantages of using this approach instead of the conventional Johansen (1998) and Johansen and Juselius (1990) approach is that while the conventional cointegration method estimates the long-run relationships within a context of a system of equations, the ARDL method employs only a single reduced form equation (Adonike, 2019; Mbah, Umunna \& Agu 2016; Pesaran \& Shin, 1995). In addition, different optimal lags can be used for the different variables, which is not applicable in the standard cointegration test. 
To make use of this method, a unit root test (with or without trend) is conducted first using the augmented Dickey Fuller test or Phillip Peron to ascertain the level of stationarity of the variables which must be a combination of I(0) and I(1) series. Following Pesaram et al (2001), the ARDL approach to cointegration involves estimating the unrestricted error correction (EC) model thus;

$\Delta P \mathrm{PV}_{t}=\beta_{0}+\beta_{1} \Delta \mathrm{LIFE}+\beta_{2} \Delta \mathrm{LAB}+\beta_{3} \Delta \mathrm{SCH}+\beta_{4}(\mathrm{POV})_{t-1}+\beta_{5} \Delta(\mathrm{LIFE})_{t-1}+\beta_{6} \Delta(\mathrm{LAB})_{t-1}+\beta_{7} \Delta(\mathrm{SCH})_{t-1}+E C T_{t-1}$

Lag length test is conducted by estimating single equation VAR and using the lag length criteria to obtain the optimal number of lags for each variable. This is followed by the estimation of a single equation unrestricted error correction model with the number of selected lags. The cointegration among the variables specified is examined using ARDL model developed by Pesaran et al. (2001) as shown below:

$\Delta \ln \mathrm{y}_{\mathrm{it}}=\beta_{0}+\sum_{i=1}^{j} \omega_{\mathrm{i}} \Delta \ln \mathrm{x}_{\mathrm{it}-\mathrm{i}} \sum_{j=1}^{k} \delta_{\mathrm{j}} \ln \mathrm{x}_{\mathrm{it}-1}+\mu_{\mathrm{it}}$

From the above, where, lny, is a vector of endogenous variables. $I=(1,2,3 \& 4)$ and $j=(1,2,3 \& 4)$. The symbol $\Delta$, is the difference operator. The long-run relationship between the variables is determined by the joint significance test of the following hypothesis: $\delta_{1}=\delta_{2}=\delta_{3}=\delta_{4}=0$. If the upper bound critical value falls below the calculated F-statistic values, the null hypotheses of no relationship are rejected, and co-integration exists among the variables that give the opportunity to estimate both long- and short-run coefficients.

The long-run equation is estimated to determine the impact of the interactive effect of the bilateral trade flows between Nigeria and China on the economic growth of Nigeria.

$\ln \mathrm{y}_{\mathrm{it}}=\lambda_{0}+\sum_{j=1}^{k} \lambda_{\mathrm{j}} \ln \mathrm{x}_{\mathrm{it}-1}+\varepsilon_{\mathrm{it}}$

Where, ln represents natural log, $\varepsilon t$ denotes white noise process whereas $y$ remains as defined under Equations (1) and (2). $i=(1,2,3 \& 4)$ and $j=(1,2,3 \& 4)$.

The short-run relationship among the series is determined using ARDL ECT specified in Equation (-2).

$$
\Delta \ln \mathrm{y}_{\mathrm{it}}=\beta_{0}+\sum_{i=1}^{k} \beta_{\mathrm{i}} \Delta \ln \mathrm{x}_{\mathrm{it}-\mathrm{i}}+\varphi_{\mathrm{i}} \mathrm{ECM}_{\mathrm{it}-1} \varepsilon_{\mathrm{it}}
$$

Where $\Delta \ln y_{i t}$ represent change in natural logarithm of all the variables specified in bilateral trade flows and economic growth models. The ECM term represents ECT it determines the magnitude of speed of adjustment. The $E C M$ measures the effectiveness or adjustment mechanism in stabilizing disequilibrium in the model specified.

\section{Empirical Results and Discussion}

The data used for this study is a time series data which is subject to unit root problems, a test of order of integration was conducted for each variable using augmented Dickey Fuller (ADF) and Phillip Perron (P-P). Prior to that, there is a check on the trend of all the variables which is shown in figure 1 below:

LIFE

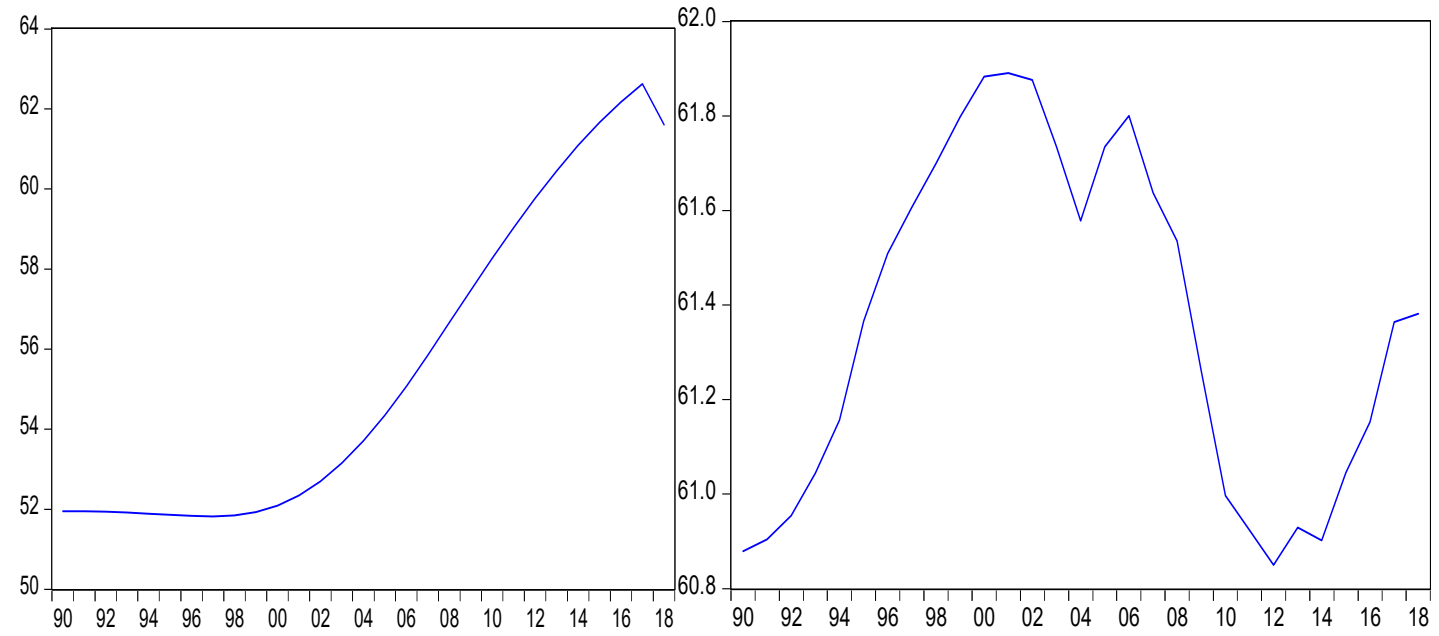



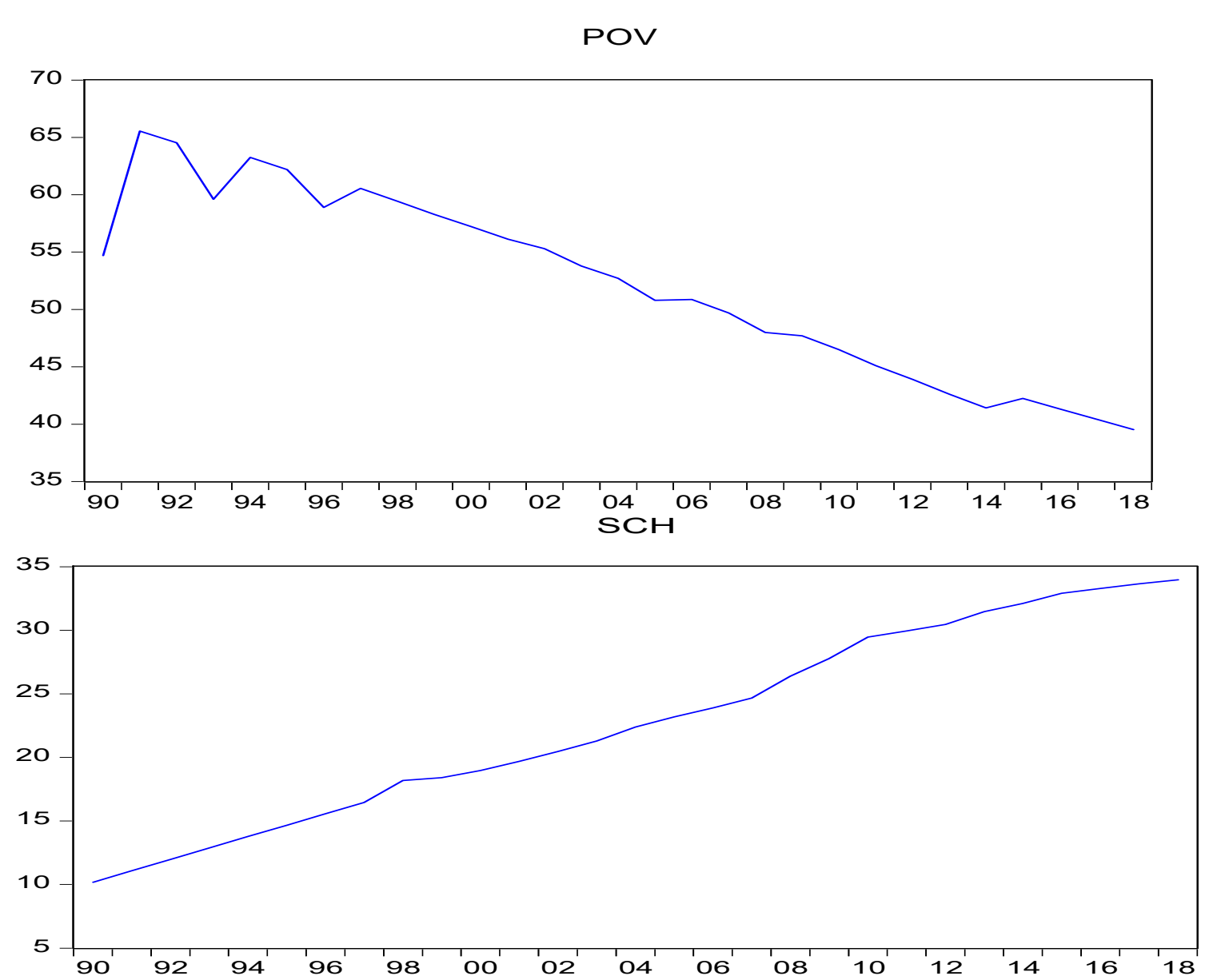

From the descriptive trends above, a critical observation of the data reveals that $\mathrm{LAB}$ have no regular trend. $\mathrm{SCH}$ and LIFE have positive trends which start very low and then rises very high to the peak level while POV curve which initially portrayed an irregular trend, started showing a very low rise to the top and then decline strongly. The trend analysis is followed by the unit root test which is represented in table 4.1 below:

The study examines the properties of the series, using ADF test:

\section{Table 4.1 ADF Unit Root Test Result}

\begin{tabular}{|l|l|l|l|l|l|}
\hline Variable & ADF Stat & Prob. Value & $\mathbf{5 \%}$ critical value & Order of Integration & Conclusion \\
\hline POV & -10.85748 & 0.0000 & -2.976263 & $1(1)$ & Stationary \\
\hline SCH & -3.857818 & 0.0069 & -2.976263 & $1(1)$ & Stationary \\
\hline $\log ($ LIFE) & -4.217450 & 0.0037 & -3.004861 & $1(0)$ & Stationary \\
\hline Log (LAB) & -6.112869 & 0.0000 & -2.981038 & $1(1)$ & Stationary \\
\hline
\end{tabular}

Source: Authors' compilation using e-views 9.1

Table 4.1 which is the result of the unit root test at level showed that POV, SCH and LLAB were stationary at $5 \%$ level of significance after first differencing. LLIFE is found to be stationary at $5 \%$ level of significance. The findings that POV, SCH and LLAB were stationary at first difference while LLIFE was stationary at level warrants the use of auto-regressive distributed lag (ARDL) model to estimate our model. The Bounds test which was used to determine if there is a long run relationship between the dependent and the independent variables also became eminent.

Table 4.2: ARDL bound test for co-integration relationship

\begin{tabular}{|l|l|l|l|l|l|l|}
\hline F-Statistics & $1 \%$ & $5 \%$ & $10 \%$ \\
\hline \multirow{2}{*}{8.011662} & Lower bound & Upper bound & Lower bound & Upper bound & $\begin{array}{l}\text { Lower } \\
\text { bound }\end{array}$ & $\begin{array}{l}\text { Upper } \\
\text { bound }\end{array}$ \\
\cline { 2 - 7 } & 4.29 & 5.61 & 3.23 & 4.35 & 2.72 & 3.77 \\
\hline
\end{tabular}

\section{Source: Author, 2020.}

The decision rule as explained by Pesaran and Shin (1999) requires that the F statistics values of any of the variables be greater than the critical bound values (pesaran values) at any significance level $(10 \%, 5 \%$, or $1 \%)$ for long run relationship to exist. With an F value of 8.011662 which is greater than both I (0) and I (1) Pesaran values at $5 \%$ level of significance shows the presence of co-integration. This means there exist a long run relationship in 
the model and as such it is imperative to estimate the co-integrating and long run form of the model as presented the Table 4.3 below:

Presentation of ARDL Result

Table 4.3: ARDL short-run Error Correction Model Result

\begin{tabular}{|l|l|l|l|l|}
\hline Variable & Coefficient & Std. Error & t-Statistic & Prob. $^{*}$ \\
\hline POV(-1) & -0.222576 & 0.216302 & -1.029008 & 0.3171 \\
\hline LAB & -0.783597 & 1.326193 & -0.590862 & 0.5620 \\
\hline LLIFE & 32.09350 & 59.80789 & 0.536610 & 0.5981 \\
\hline LLIFE(-1) & -357.9574 & 162.8679 & -2.197838 & 0.0413 \\
\hline SCH & 293.4100 & 118.5334 & 2.475337 & 0.0235 \\
\hline SCH(-1) & 0.045407 & 0.623335 & 0.072845 & 0.9427 \\
\hline SCH(-2) & -0.083385 & 0.849634 & -0.098142 & 0.9229 \\
\hline C & -0.820745 & 0.643444 & -1.275550 & 0.2183 \\
\hline R-squared & 262.1936 & 172.3662 & 1.521143 & 0.1456 \\
\hline F-statistic & 0.987503 & Mean dependent var & 51.55481 \\
\hline Prob(F-statistic) & 177.7952 & Durbin-Watson stat & 2.497379 \\
\hline
\end{tabular}

Source: Authors' computation using E-views 9.1

Table 4.4: ARDL normalized Long-run coefficients

\begin{tabular}{|l|l|l|l|l|}
\hline Variable & Coefficient & Std. Error & t-Statistic & Prob. \\
\hline C & 214.459940 & 133.663052 & 1.604482 & 0.1260 \\
\hline LAB & -0.640939 & 1.072158 & -0.597803 & 0.5574 \\
\hline LLIFE & -26.545457 & 18.904372 & -1.404197 & 0.1773 \\
\hline SCH & $-0.702388^{* *}$ & 0.178461 & -3.935806 & 0.0010 \\
\hline ECM (-1) & -1.222576 & 0.216302 & -5652185 & 0.0000 \\
\hline
\end{tabular}

** significant at $5 \% *$ significant at $1 \%$

Source: Authors' computation (E-views), 2020

Table 4.3 above, shows the coefficient of life expectancy at birth for females in Africa to be 32.09350 which indicates a positive relationship between Poverty headcount ratio for Africa (POV) and life expectancy at birth for females in Africa. It implies that a $1 \%$ increase in life expectancy will lead to a $32.09 \%$ rise in poverty level in Nigeria. The $\mathrm{p}$ value at 0.5981 shows that life expectancy of the female is not significant in affecting poverty at $5 \%$ level of significance. The value of the coefficient of school enrolment stood at 0.045407 and the p value stood at 0.9427 . It indicates a positive and insignificant relationship between life expectancy of female in Africa and poverty rates in Africa, meaning that a $1 \%$ increase in life expectancy will lead to $4.5 \%$ increases in poverty rates. Similarly, LLAB coefficient -0.783597 indicates that $1 \%$ increase in LAB decreases POV by $78 \%$. Also, its $p$ value of 0.5620 indicates an insignificant impact of LAB on POV. The coefficient of cointegration (ECM (-1)) which denote the speed of adjustment stood at -1.222576 with a p-value of 0.0000 (statistically significant) means that $122 \%$ of the disequilibrium in the model will be corrected annually.

The result in table 4.3 also shows the value of $\mathrm{R}$ squared $\left(\mathrm{R}^{2}\right)$ which shows that the overall goodness of the model is 0.987503 , meaning that about $99 \%$ of the variation in POV is explained by the explanatory variables, that is female Labor force participation rate, school enrolment for female and life expectancy for female in Africa in the model. The F-statistic which measures the joint statistical influence of the explanatory variables in explaining the dependent variable stood at 177.7952 with a p value of 0.000000 . This implies that the explanatory variables are important determinants of POV. It also indicates the influence of the explanatory variables to be statistically significant at $5 \%$ level of significance. The Durbin-Watson test for auto correlation shows that the error terms are not serially correlated since it is approximately equal to two $(\approx 2.497)$.

In the normalized estimated long run coefficients as shown in table 4.6 above, Female Labor force participation rate (LAB), and Life expectancy at birth for females in Africa (LLIFE) show negative and insignificant relationship whereby any unit change in LAB and LIFE will lead to a $0.64 \%$ and $2655 \%$ change in POV respectively in the long run. Also, School enrollment for females in Africa ( $\mathrm{SCH})$ showed negative and significant impact on poverty headcount ratio in Africa in the long run. The result further implies that a unit increase in LAB, LIFE and $\mathrm{SCH}$ will lead to a $64 \%, 65 \%$ and $70 \%$ decreases in POV respectively and vice versa in the long run. The ECM (-1) of -1.22 is the speed of adjustment from the short-run equilibrium to the long-run equilibrium. The model is checked for autocorrelation using the Breusch-Godfrey Serial Correlation LM Test which is shown in table 4.5 below 
Table 4.5: Serial Correlation Test

\begin{tabular}{|l|l|l|l|}
\hline \multicolumn{3}{|l|}{ Breusch-Godfrey Serial Correlation LM Test: } & \\
\hline F-statistic & 8.343802 & Prob. F(2,21) & 0.0033 \\
\hline Obs*R-squared & 13.78398 & Prob. Chi-Square(2) & 0.0010 \\
\hline
\end{tabular}

Source: Authors' computation (E-views9.1), 2020

The Table 4.5 above presents the result of the Breusch-Godfrey test for serial correlation. From the value of the prob. Chi-Square of 0.0010 , we cannot reject the null-hypothesis of no auto correlation which is desirable in the model. This therefore indicates the absence of autocorrelation in the model.

Table 4.6 Heteroskedasticity Test: Breusch-Pagan-Godfrey Test

\begin{tabular}{|c|c|c|c|}
\hline \multicolumn{4}{|c|}{ Heteroskedasticity Test: Breusch-Pagan-Godfrey: } \\
\hline F-statistic & 3.154596 & Prob. F $(8,18)$ & 0.0204 \\
\hline Obs*R-squared & 15.75957 & Prob. Chi-square (8) & 0.0460 \\
\hline Scaled explained SS & 14.60759 & Prob. Chi-square (8) & 0.0672 \\
\hline
\end{tabular}

Source: Authors' computation (using E-views 9.1), 2020

The Breusch-Godfrey test for heteroscedasticity is conducted to check if errors have constant variance or not. The null hypothesis is that the errors are homoscedastic (no heteroscedasticity). Note that this test follows a chi square distribution. We compare the estimated chi square probability value with the critical chi-square probability at $5 \%$ level of significant. From the result obtained $X^{2}$ Prob $=0.0460$ which is statistically significant, we accept the null hypothesis and conclude that there is homoscedasticity in our data which implies that the residuals have constant variance.

\section{Conclusion and Recommendations}

In response to the devastating poverty rates across the African continent (especially in the sub Saharan region) and with the continent being the poorest continent in the world, this study investigated the extent to which female capability on the African continent has been expanded for poverty reduction strategies and development through health, education and employment to help ameliorate the situation. The study has established that school enrollment (secondary) for females in Africa has shown to be a significant long run strategy towards expanding female capability for poverty reduction on the continent. Thus, this implies that if the literacy level of women were enhanced through improved school enrolment, poverty on the continent will reduce very significantly in the long run.

Based on the outcome of this study, it is imperative to recommend to the African authorities to put in more efforts in expanding female capability towards reducing poverty on the continent. This can be accomplished through the following ways:

i. Knowing that school enrolment of women has the potency of reducing poverty, effective women education policy interventions should be implemented by the leaders in education sector in Africa to mitigate against the increasing rate of poverty suffered in Africa.

ii. As a matter of urgency, massive infrastructural and intervention efforts should be invested on the health sector so as to help improve the life expectancy of females on the continent to enhance the productivity needed for poverty reduction and sustainable development.

iii. Central governmental agencies such as African Union, etc., should encourage their member states to invest heavily in improving literacy rates especially among the girl children, as this will have a long run impact on poverty reduction on the continent.

\section{References}

Abdourahman, O. I. (2010). Time Poverty: A Contributor to Women's Poverty? Journal Statistique Africain, 1(11), 16-37.

Adonike, K. C., (2019). Analysis of Nigeria-China Bilateral Trade Relations: Implications for Economic Growth in Nigeria (Unpublished master's thesis proposal). Nnamdi Azikiwe University. Awka.

African Union Development Agency (2019). Empowering African women: a way to make Africa stronger. Retrieved from https:/www.nepad.org/news/empowering-african-women-way-make-africa-stronger. accessed 02/03/2020.

Africare (2010). Women's Empowerment. Retrieved from https://www.africare.org/africares-approach/womensempowerment/. accessed 03/03/2020.

Ajala, C. G., \& Fakoya, E. O. (2003). Women's small-scale business activities towards poverty alleviation in Ibadan North-East Local Government area of Oyo State. Asset Series. 3(1),1-6.

Aku, P.S., Ibrahim M.T., \& Bulus, Y.D. (2007). Perspectives on Poverty Alleviation Strategies in Nigeria. Ibadan: Journal of Nigerian Economic Society, 1(6), 41-51.

Audu, H.O., \& Okpe, I.J. (2018). Women in small scale enterprises and poverty reduction in Dekina Local Government area of Kogi state: A logistic regression approach. Journal of Economics and Finance, 9(3), 64-71. 
IFAD (2002). Enabling the Rural Poor to Overcome their Poverty. Retrieved from https://www.google.com/url?sa=t\&rct=j\&q=\&esrc=s\&source=web\&cd=5\&ved=2ahUKEwjrqoH5oP_nAh UFQhUIHbqdA4sQFjAEegQIAxAB\&url=https $\% 3 \mathrm{~A} \% 2 \mathrm{~F} \% 2 \mathrm{Fwww}$.ifad.org\%2Fdocuments\%2F38714170 \%2F39309797\%2FIFAD\%2Bannual\%2Breport\%2B2002\%2B\%2Bpart\%2B1_e.pdf\%2Fd20eb7b8-30d2454a-b65c9accbff8eb1d\&usg=AOvVaw2MKrqsivXzdjsSp3KqJ7Gv. accessed 03/03/2020.

ILO (2016). Young and Female- a Double Strike? Retrieved from https://www.ilo.org/employment/areas/youthemployment/work-for-youth/publications/thematic-reports/WCMS_447495/lang--en/index.htm accessed 02/03/2020.

Johansen, S. (1998). "Statistical analysis of cointegration vectors". Journal of Economic Dynamics and Control, $12(1), 12-22$.

Johansen, S., \& Juselius, K. (1990). Maximum Likelihood Estimation and Inference on Cointegration with Applications to Demand for Money. Oxford Bulletin of Economics and Statistics, 52(1), 169-210.

Jonathan, E.O., Victor A. M., \& Tuluma I. E. (2013). Small scale enterprises, poverty alleviation and job creation in Nigeria: lessons from burnt bricklayers in Benue State. Journal of Economics \& Sustainable Development, $4(18), 1-15$.

Kabeer, N. (2015). Gender, Poverty, and Inequality: A Brief History of Feminist Contributions in the Field of International Development. Journal of Gender \& Development 23(2), $189-205$.

Mbah, S. A., Umunna G., \& Agu O. C. (2016). Impact of External Debt on Economic Growth in Nigeria: An ARDL Bound Testing Approach. Proceedings of the Fifth Middle East Conference on Global Business, Economics, Finance and Banking (ME16Dubai October Conference) ISBN: 978-1-943579-27-3.

Nwora, N. G. (2019). Adopting Marketing Mix Model for Reducing Poverty Incidence in Nigeria. Journal for Tourism and Hospitality 19(8), 72-396.

Obadan, M. I. (2006). Analytical Framework for Poverty Reduction: Issues of Economic Growth Versus other Strategies. Nigerian Economic Society Annual Conference.

Okoh, R. N. (2007). The Concept of Poverty and its Measurements. Nigerian Journal of Economic and Social Studies. 1(39), 221-229.

Ozoh J. N., Metu, A.G., Chukwuka, S.M., \& Madueke, C. (2020). Poverty Alleviation Programme and Poverty Reduction in Anambra State. Evidence from Women Business Ownership. Advances in Social Sciences Research Journal, 7(1), 217-229.

Patel, N. (2018). Figure of the week: Understanding poverty in Africa. Retrieved from https://www.brookings.edu/blog/africa-in-focus/2018/11/21/figure-of-the-week-understanding-poverty-inafrica/.

Pesaran, H. M., \& Shin, Y. (1995). Autoregressive Distributed Lag Modelling Approach to Cointegration Analysis. DAE Working Paper Series No. 9514 (Cambridge: Department of Applied Economics, University of Cambridge).

Pesaran, H. M., \& Shin, Y. (1999). "Autoregressive distributed lag modelling approach to cointegration analysis", in: S. Storm (Ed.) Econometrics and Economic Theory in the 20th Century: The Ragnar Frisch Centennial Symposium, chapter 11, Cambridge: Cambridge University Press.

Sen, A. (2000). Development as Freedom. New Delhi: Oxford University Press.

Sen, A. (1981). Poverty and Famines: An Essay on Entitlement and Deprivation. Oxford: Clarendon Press.

Suraidi, M. T. (2014). Amartya Sen's Capabilities Approach to Poverty. Retrieved from https://www.woroni.com.au/words/amartya-sens-capabilities-approach-to-poverty/. accessed 03/02/2020.

Weistein, S.L.W. (2019). Women's Empowerment as a Policy for Poverty Reduction in Haiti. (Unpublished Dissertation). Walden: Walden University.

World Bank, (2017). Monitoring Global Poverty: Report of the Commission on Global Poverty. Washington DC: World Bank.

World Bank, (2018). Piercing Together the Poverty Puzzle. Washington DC: World Bank.

World Bank Development Report, (2018). A Continent in Transition: Sub-Saharan Africa in the Mid-1990s. Washington DC: World bank.

\section{Authors Biography:}

Uzonwanne Maria Chinecherem is a citizen of Nigeria. She is a Lecturer in the Department of Economics, Nnamdi Azikiwe University Awka, Anambra State, Nigeria. She obtained her B.sc (2008), M.sc (2009) and PhD degree (2012) in Development Economics at the Pontifical Gregorian University Rome, Italy. She is a member of many professional bodies such as Nigerian Economic Society, Association for the Advancement of African Women Economist (AAAWE), Nigerian Association for Energy and Environmental Economics (NAEEE), International Association for Female Academic Doctors (IAFAD), Academic Staff Union of University (ASUU) and Fellow, Center for Migration, Nnamdi Azikiwe University, Awka. She is also a consultant with African Development Institute. 